\title{
EMOTIONAL QUESTION OF STUDENTS IN UNDERGRADUATE COURSE OF SCHOOL OF NURSING - HASANUDDIN UNIVERSITY
}

\author{
Desy Ana Hendra ${ }^{1}$, Hapsah $^{2}$, Silvia Malasari ${ }^{3}$, Yuliana Syam $^{4}$, Andriani ${ }^{5}$ \\ 1,2,3,4,5 Program Studi Ilmu Keperawatan Universitas Hasanuddin \\ e-mail: desyanahendra@gmail.com
}

\begin{abstract}
Introduction: Lower level of caring in Indonesian nurses related to emotional intelligence level of nursing, and assertion to nurses for always being professional in any circumstances and this condition relatated to emotional intelligence which is formed when undergoing nursing education along emotional intelligence phenomena in nurses period of education and period of profession education between regular students and non-regular students. Method: the design of this study is descriptive research with crossectional approach. Sample selection technique using disproportionate stratified random sampling, with the number of respondent about 128 respondents. Primary data was obtained through a TEIQUE questionnaire in the form of question about Emotional Itelligence and the ability of recognizing emotion, managing emotion, self motivation, empathy, social skill. Result: This study shows that, $55 \%$ respondents have a high emotional intelligence and higer in term of recognizing emotion ability $(80.5 \%)$, managing emotion ability (56.3\%), self motivation ability (92.2\%), empathy ability (59.4\%), and social skill ability $(63.3 \%)$. Respondent characteristics who have higer in emotional intelligence were from adults (56.4\%), woman (56.4\%), unreguler students $(96.4 \%)$, widow/widowed marriage status $(69.2 \%)$, student who do not entered any organization $(76.1 \%)$, and students in seventh grade $(69.4 \%)$.Conclusion: the result showed that more than half respondents have higer emotional intelligence (managing emotion ability, self motivation ability, empathy ability, social skill ability ) so that give us information about description of Emotional Intelligence in Undergraduate Hasanuddin University Nursing Students.
\end{abstract}

Keywords : Emotional intelligence, nursing students

\section{PENDAHULUAN}

Keperawatan adalah sebuah profesi yang sangat dituntut untuk profesional dalam setiap tindakan dan kesehariannya. Perawat dalam kehidupan profesionalnya, sudah jelas akan terpapar langsung dengan ribuan emosi manusia yang terdiri atas ketidaknyamanan, nyeri, kesedihan dan kehilangan harapan (Freshwater \& Stickley, 2009). Oleh karena itu, seorang perawat yang profesional dituntut untuk mampu memiliki soft skill dalam hal ini kecerdasan emosional yang terdiri atas kemampuan mengenali emosi diri, mengelola emosi, memotivasi diri sendiri, mengenali emosi orang lain (empati), serta kemampuan dalam membina hubungan (social skill) yang mumpuni (Goleman, 2015).

Kecerdasan emosional berdampak pada perilaku caring perawat (Kaur, Sambasivan, \& Kumar, 2015). Tingkat caring perawat Indonesia masih dikategorikan rendah. Penelitian Sukesi (2012) menemukan bahwa hanya $34 \%$ pasien yang puas akan kinerja perawat termasuk didalamnya perilaku caring dan data ini menunjukan adanya masalah terhadap proses pembentukan kecerdasan emosional perawat yang sebagian besar terbentuk pada saat perawat tersebut masih menjadi mahasiswa (Freshwater \& Stickley, 2009).

Pendidikan merupakan salah satu faktor yang berpengaruh terhadap kecerdasan emosional. Hal ini telah dibuktikan oleh Shanta \& Gargiulo 
(2014) bahwa mahasiswa perawat senior memiliki kecerdasan emosional yang lebih baik dibandingkan mahasiswa yang baru. Pendidikan dalam keperawatan merupakan tombak utama yang membentuk kecerdasan emosional. Mengingat dalam masa ini, calon perawat akan banyak belajar mengenai konsep caring dan asuhan keperawatan yang efektif (Ranjbar, 2015).

Terdapat banyak penelitian mengenai pentingnya kecerdasan emosional bagi perawat namun belum terdapat Institusi di Indonesia yang mengidentifikasi lebih dalam terkait pencapaian kecerdasan emosional mahasiswa perawat yang akan dipersiapkan untuk menjadi seorang perawat.

Pengalaman klinik juga mendukung kecerdasan emosional yang lebih baik dibandingkan dengan yang belum memiliki pengalaman klinik (Foster, McCloughen, Delgado, Kefalas, \& Harkness, 2015). Hal inilah yang juga terlihat dalam lingkup Institusi Pendidikan Keperawatan Universitas Hasanuddin dalam hal ini adalah Program Studi Ilmu Keperawatan (PSIK). Terdapat dua jenis jalur seleksi penerimaan mahasiswa yakni program reguler dan program kerjasama, dimana program reguler berisi oleh mahasiswa yang belum memiliki pengalaman klinis sedang program kerja sama adalah mahasiswa yang telah memiliki pengalaman klinis sebelumnya.

Mahasiswa program reguler seringkali mengalami masalah dalam proses pembelajaran, dibandingkan dengan program kerjasama. Saat dalam masa profesi, mahasiswa program reguler sering kurang menampilkan caring terhadap pasien. Tidak hanya itu, mereka juga mengalami kesulitan dalam memotivasi diri dan peka sosial. Krisis attitude merupakan hal paling sering dialami dan semua hal tersebut sangat berkaitan dengan kecerdasan emosional (Goleman, 2015).

Berdasarkan pemaparan ini, penelitian yang bertujuan untuk melihat gambaran kecerdasan emosi yang dimiliki oleh mahasiswa PSIK Unhas dalam masa studi Strata Satu Keperawatan sangat penting dilakukan. Dimana penelitian ini akan melihat kecerdasan emosional mahasiswa keperawatan Unhas beserta kelima aspek kecerdasan emosional yang terdiri atas kemampuan mengenali emosi diri, mengelola emosi, memotivasi diri, mengenali emosi orang lain (empati), serta kemampuan dalam membina hubungan (social skill) yang mumpuni (Goleman, 2015) serta mengidentifikasi kecerdasan emosional berdasarkan karakteristik responden seperti usia, jenis kelamin, jenis program masuk PSIK Unhas, status pernikahan orangtua, pengalaman organisasi, dan semester perkuliahan.

\section{METODE}

Studi ini merupakan penelitian kuantitatif- deskriptif dengan pendekatan cross sectional. Dimana dalam penelitian ini, peneliti mencoba memberikan gambaran tentang kecerdasan emosi pada mahasiswa S1 PSIK Unhas.

\section{HASIL}

Distribusi frekuensi dengan crosstabulasi untuk mengukur gambaran kecerdasan. Hasil penelitian sebagai berikut: karakteristik responden (tabel 1.), kecerdasan emosional (table 2), kemampuan mengenali emosi diri (tabel 3), kemampuan mengelola emosi (tabel 4), kemampuan memotivasi diri (tabel 5), kemampuan empati (tabel 6), social skill (tabel 7), kecerdasan emosional berdasarkan karakteristik responden (tabel 8) 


\begin{tabular}{|c|c|c|}
\hline Karakteristik & $\mathbf{f}$ & $\%$ \\
\hline \multicolumn{3}{|l|}{ Usia } \\
\hline Remaja & 35 & 27.3 \\
\hline Dewasa awal & 93 & 72.7 \\
\hline \multicolumn{3}{|l|}{ Jenis Kelamin } \\
\hline Laki-Laki & 20 & 15.6 \\
\hline Perempuan & 108 & 84.4 \\
\hline \multicolumn{3}{|l|}{ Jenis Program } \\
\hline Program reguler & 100 & 78.1 \\
\hline Program kerjasama & 28 & 21.9 \\
\hline \multicolumn{3}{|c|}{$\begin{array}{l}\text { Status pernikahan orang } \\
\text { tua }\end{array}$} \\
\hline Menikah & 107 & 83.6 \\
\hline Cerai hidup & 4 & 3.1 \\
\hline Cerai mati & 13 & 10.2 \\
\hline Kematian & 4 & 3.1 \\
\hline \multicolumn{3}{|c|}{ Pengalaman Berorganisasi } \\
\hline Sangat aktif & 10 & 7.8 \\
\hline Aktif & 74 & 57.8 \\
\hline Kurang aktif & 23 & 23 \\
\hline Tidak aktif & 21 & 21 \\
\hline \multicolumn{3}{|l|}{ Semester } \\
\hline Semester 1 & 27 & 21.1 \\
\hline Semester 3 & 26 & 20.3 \\
\hline Semester 5 & 39 & 30.5 \\
\hline Semester 7 & 36 & 28.1 \\
\hline
\end{tabular}

\begin{tabular}{lcc}
\hline Kecerdasan Emosional & f & \% \\
\hline Tinggi & 71 & 55.5 \\
Rendah & 57 & 44.5 \\
Total & 128 & 100
\end{tabular}

Table 2. Distribusi Frekuensi Responden berdasarkan Kecerdasan Emosional Mahasiswa dalam masa studi Strata Satu PSIK UNHAS

\begin{tabular}{lcc}
\hline Mengenali Emosi Diri & f & \% \\
\hline Tinggi & 103 & 80.5 \\
Rendah & 25 & 19.5 \\
Total & 128 & 100
\end{tabular}

Table 3. Distribusi Frekuensi berdasarkan Kemampuan Mengenali Emosi Diri dalam masa studi Strata Satu PSIK UNHAS

\begin{tabular}{lcc}
\hline Mengelola Emosi & f & \% \\
\hline Tinggi & 72 & 56.3 \\
Rendah & 56 & 43.8 \\
Total & 128 & 100
\end{tabular}

Table 4. Distribusi Frekuensi Responden berdasarkan Kemampuan Mengelola Emosi dalam masa studi Strata Satu PSIK UNHAS 


\begin{tabular}{lcc}
\hline Motivasi Diri & f & \% \\
\hline Tinggi & 118 & 92.2 \\
Rendah & 10 & 7.8 \\
Total & 128 & 100
\end{tabular}

Table 5. Distribusi Frekuensi berdasarkan Kemampuan Memotivasi Diri Mahasiswa dalam masa studi Strata Satu PSIK UNHAS

\begin{tabular}{lcc}
\hline Empati & f & \% \\
\hline Tinggi & 76 & 59.4 \\
Rendah & 52 & 40.6 \\
Total & 128 & 100
\end{tabular}

Table 6. Distribusi Frekuensi berdasarkan Kemampuan Empati Mahasiswa dalam masa studi Strata Satu PSIK UNHAS

\begin{tabular}{lcc}
\hline Social Skill & f & $\%$ \\
\hline Tinggi & 81 & 63.3 \\
Rendah & 47 & 36.7 \\
Total & 128 & 100 \\
Table 7. Distribusi Frekuensi Kemampuan Mengenali Emosi Orang Lain (Social Skill)
\end{tabular}

dalam masa studi Strata Satu PSIK UNHAS

Berdasarkan tabel 1 menunjukkan bahwa mayoritas responden berada pada fase dewasa awal (19-39 tahun) sebanyak 93 orang $(72.7 \%)$, sebagian besar responden berjenis kelamin perempuan dengan jumlah sebanyak 108 orang $(72.7 \%)$, mayoritas responden adalah program regular sebanyak 100 orang (78.1 $\%)$, mayoritas responden memiliki status pernikahan orang tua menikah sebanyak 107 orang (83.6\%), lebih dari setengah jumlah responden memiliki pengalaman berorganisasi dengan kriteria aktif yakni sebanyak 74 orang $(57.8 \%)$ dan kurang dari setengah semester 5 sebanyak 39 orang (30.5\%).

Tabel 2 menunjukkan bahwa lebih dari setengah responden sebanyak 71 orang $(55.5 \%)$ memiliki kecerdasan emosional yang tinggi.

Tabel 3 menunjukkan bahwa mayoritas responden sebanyak 103 orang $(80.5 \%)$ memiliki gambaran kemampuan mengenali emosi diri yang tinggi. Tabel 4 didapatkan bahwa lebih dari setengah responden sebanyak 72 orang $(56.3 \%)$ memiliki gambaran kemampuan mengelola emosi diri yang tinggi

Tabel 5 didapatkan bahwa mayoritas responden sebanyak 118 orang $(92.2 \%)$ memiliki gambaran kemampuan memotivasi diri yang tinggi. Tabel 6 didapatkan bahwa lebih dari setengah responden sebanyak 76 orang $(59.4 \%)$ memiliki gambaran kemampuan empati yang tinggi

Tabel 7 didapatkan bahwa lebih dari setengah responden sebanyak 81 orang $(63.3 \%)$ memiliki gambaran kemampuan mengenali emosi orang lain (social skill) yang tinggi. 


\begin{tabular}{|c|c|c|c|c|c|c|}
\hline \multirow{3}{*}{ Karakteristik } & \multicolumn{4}{|c|}{ Kecerdasan emosional } & \multirow{2}{*}{\multicolumn{2}{|c|}{ Total }} \\
\hline & \multicolumn{2}{|c|}{ Ringgi } & \multicolumn{2}{|c|}{ Rendah } & & \\
\hline & $\mathbf{f}$ & $\%$ & $\mathbf{f}$ & $\%$ & $\mathbf{f}$ & $\%$ \\
\hline \multicolumn{7}{|l|}{ Usia } \\
\hline Remaja & 15 & 42.8 & 20 & 57.1 & 35 & 100 \\
\hline Dewasa awal & 56 & 60.2 & 37 & 39.7 & 93 & 100 \\
\hline Total & 71 & 55.4 & 57 & 44.5 & 128 & 100 \\
\hline \multicolumn{7}{|l|}{ Jenis Kelamin } \\
\hline Laki-laki & 10 & 50 & 10 & 10 & 20 & 100 \\
\hline Perempuan & 61 & 56.4 & 47 & 43.5 & 108 & 100 \\
\hline Total & 71 & 55.4 & 57 & 44.5 & 128 & 100 \\
\hline \multicolumn{7}{|l|}{ Jenis Program } \\
\hline Program reguler & 44 & 44 & 56 & 56 & 100 & 100 \\
\hline Program kerjasama & 27 & 96.4 & 1 & 43.5 & 28 & 100 \\
\hline Total & 71 & 55.4 & 57 & 44.5 & 128 & 100 \\
\hline \multicolumn{7}{|c|}{ Status pernikahan orangtua } \\
\hline Menikah & 58 & 54.2 & 49 & 45.7 & 107 & 100 \\
\hline Cerai Hidup & 2 & 50 & 2 & 50 & 4 & 100 \\
\hline Cerai Mati & 9 & 69.2 & 4 & 30.7 & 13 & 100 \\
\hline Kematian keduanya & 2 & 50 & 2 & 50 & 4 & 100 \\
\hline Total & 71 & 55.4 & 57 & 44.5 & 128 & 100 \\
\hline \multicolumn{7}{|l|}{ Pengalaman organisasi } \\
\hline Sangat aktif & 4 & 40 & 6 & 60 & 10 & 100 \\
\hline Aktif & 37 & 50 & 37 & 50 & 74 & 100 \\
\hline Kurang aktif & 14 & 60.8 & 9 & 39.1 & 23 & 100 \\
\hline Tidak aktif & 16 & 76.1 & 5 & 23.8 & 21 & 100 \\
\hline Total & 71 & 55.4 & 57 & 44.5 & 128 & 100 \\
\hline \multicolumn{7}{|l|}{ Semester } \\
\hline Satu & 13 & 48.1 & 14 & 51.8 & 27 & 100 \\
\hline Tiga & 10 & 38.4 & 16 & 61.5 & 26 & 100 \\
\hline Lima & 23 & 58.9 & 16 & 41 & 39 & 100 \\
\hline Tujuh & 25 & 69.4 & 11 & 30.5 & 36 & 100 \\
\hline Total & 71 & 55.4 & 57 & 44.5 & 128 & 100 \\
\hline
\end{tabular}

Tabel 8 1. Distribusi Frekuensi Kecerdasan Emosional Berdasarkan Karakteristik Mahasiswa dalam masa studi Strata Satu Program Studi Ilmu Keperawatan Universitas Hasanuddin

Tabel 8 menunjukkan lebih dari setengah usia dewasa memiliki kecerdasan emosional yang tinggi sebanyak 56 (60.2 \%), lebih dari setengah perempuan memiliki kecerdasan emosional yang tinggi sebanyak 61 orang $(56.4 \%)$, mayoritas program kerjasama memiliki kecerdasan emosional yang tinggi sebanyak 27 (96.4\%), lebih dari setengah status pernikahan orang tua cerai mati memiliki kecerdasan emosional yang tinggi sebanyak 9 orang $(69.2 \%)$, mayoritas mahasiswa dengan status organisasi tidak aktif memiliki kecerdasan emosional yang tinggi sebanyak 16 orang $(76.1 \%)$, dan lebih dari setengah mahasiswa di semester tujuh memiliki kecerdasan emosional yang tinggi (69.4\%). 


\section{PEMBAHASAN \\ Kecerdasan emosional}

Kecerdasan emosional adalah kemampuan untuk merasakan, memahami secara efektif, menerapkan daya dan kepekaan emosi sebagai sumber energi, informasi, koneksi dan pengaruh manusia (Agustian, 2005). Hasil penelitian yang telah dilakukan pada 128 responden tentang kecerdasan emosional mahasiswa, menunjukkan bahwa lebih dari setengah jumlah responden memiliki kecerdasan emosional yang tinggi yaitu $55.5 \%$ atau sebanyak 71 orang. Namun faktanya, mahasiswa yang memiliki kecerdasan emosional rendah hampir mencapai setengah dari responden yaitu sebanyak $44.5 \%$ atau 57 orang.

Banyaknya mahasiswa yang memiliki kecerdasan emosi rendah menunjukkan bahwa terdapat masalah saat pembentukan kecerdasan tersebut. Goleman (2015) menyatakan bahwa kecerdasan emosional yang rendah memungkinkan adanya proses yang hilang, dimana proses tersebut dipengaruhi oleh faktor internal dan faktor eksternal. Faktor eksternal yang meliputi lingkup masyarakat, lingkup pertemanan, lingkungan akademik merupakan faktor penentu dalam proses pembentukan kecerdasan emosional (Goleman, 2015).

Kecerdasan emosi mahasiswa dipengaruhi banyak faktor. Proses pendidikan sangat berperan dalam pembentukan kecerdasan emosi mahasiswa perawat (Shanta \& Gargiulo, 2014). Kecerdasan emosional yang rendah juga disebabkan oleh adanya proses yang hilang dalam masa pendidikan baik dalam masa pembelajaran demi menguasai ilmu pengetahuan dan teknologi, penyelesaian masalah, membentuk sikap dan perilaku professional, masa pembelajaran aktif dan mandiri, dan masa pembelajaran saat di dalam masyarakat (Nursalam \& Efendi, 2006).

Kecerdasan emosi ini punya andil yang besar terhadap kinerja dan penampilan seorang perawat.
Rendahnya kecerdasan emosi tentunya akan berdampak terhadap kinerja seorang perawat nantinya. Menurut Smith, Profetto-McGrath, \& Cummings (2011), kecerdasan emosional berpengaruh terhadap kemampuan seorang perawat dalam memimpin. Beauvais, Brady, O'Shea, \& Griffin (2011) menemukan bahwa perawat yang memiliki kecerdasan emosional tinggi memiliki dimensi performa di atas ratarata yang terdiri atas kepemimpinan, critical care, kolaborasi, perencanaanevaluasi, hubungan interpersonal dan pengembangan profesional.

Terdapat banyak dampak yang bagi perawat yang memiliki kecerdasan emosional yang rendah, namun kecerdasan emosi ini dapat di kembangkan dan ditingkatkan melalui training psikologi dan sosial (Ilievova, Juhasova, \& Baumgartner, 2013)

\section{Kemampuan mengenali emosi diri}

Hasil penelitian terhadap 128 responden tentang kemampuan mengenali emosi diri menunjukkan bahwa mayoritas responden memiliki kecerdasan emosional yang tinggi yaitu sebanyak 103 orang (80.5 \%) meskipun ditemukan juga terdapat 25 orang yang memiliki kemampuan mengenali emosi yang rendah yaitu 25 orang (19.5\%).

Hal ini sesuai dengan Freshwater \& Stickley (2009) yang mengatakan bahwa kemampuan mengenali emosi diri bagi mahasiswa sangat penting bagi seorang perawat untuk mengambil keputusan. Sedangkan untuk 25 responden yang memiliki kemampuan mengenali emosi rendah dikarenakan hilangnya proses dalam pembentukan kemampuan ini, saat belajar mengambil keputusan dan belajar meyakinkan dirinya atas perasaannya (Goleman, 2015)

Kemampuan mengenali emosi diri sangat penting untuk mengambil keputusan. Rendahnya kemampuan ini menyebabkan keragu-raguan dalam mengambil tindakan dan akan berdampak terhadap kesembuhan pasien (Linda \& Connoly, 2013) 
Kemampuan mengelola emosi diri Mengenai kemampuan mengelola emosi diri didapatkan bahwa lebih dari setengah responden memiliki gambaran kemampuan mengelola emosi yang tinggi sebanyak 72 orang $(56.3 \%)$ meskipun pun terdapat 56 orang (43.8 \%) yang memiliki kemampuan mengelola emosi yang rendah.

Dalam penelitian ini, didapatkan bahwa usia remajalah yang banyak memiliki kemampuan mengelola emosi yang rendah. Sama dengan yang dikemukakan oleh Arsana (2016), bahwa usia merupakan faktor pembentuk kemampuan mengelola emosi. Kemampuan mengelola emosi yang rendah ini mayoritas berasal dari mahasiswa program regular. Foster, McCloughen, Delgado, Kefalas, \& Harkness (2015) juga mendapatkan bahwa pengalaman klinik sebelumnya mempengaruhi pembentukan kemampuan mengelola emosi. Kemampuan yang rendah ini juga paling banyak pada mahasiswa semester satu. Sesuai dengan Shanta \& Gargiulo (2014) menemukan bahwa kemampuan mengelola emosi adalah bagian dari kecerdasan emosional yang berkembang ke arah yang baik pada mahasiswa yang lebih senior.

Kemampuan mengelola emosi yang rendah ini dapat disebabkan karena gagalnya proses belajar dalam membentuk kemampuan ini. Proses belajar mengelola emosi terletak saat dihadapkan pada keadaan yang sulit sehingga muncul koping individu untuk menghibur diri dan melepaskan kecemasan, kemurungan dan ketersinggungan (Goleman, 2015).

Kemampuan mengelola emosi yang rendah berakibat pada ketidakmampuan perawat beradaptasi dan berespon dengan tepat terhadap reaksi emosi pasien, kolega dan lingkungan yang kacau (Linda \& Connoly, 2013). Kemampuan mengelola emosi sangat dibutuhkan oleh mahasiswa dikarenakan perawat adalah profesi yang penuh dengan tantangan.

Penelitian ini juga mendapatkan bahwa mayoritas responden sebanyak 118 orang $(92.2 \%)$ memiliki gambaran kemampuan motivasi diri yang tinggi. Namun juga ada 10 orang $(7.8 \%)$ yang memiliki kemampuan motivasi diri yang rendah.

\section{Motivasi diri}

Hasil penelitian ini, membuktikan bahwa sebagian besar mahasiswa keperawatan Unhas memiliki motivasi yang baik. Motivasi ini yang mendorong seseorang untuk terus memiliki kinerja yang baik serta lebih produktif (Goleman, 2015). Hal ini dibuktikan dalam penelitian ini bahwa terdapat 74 orang $(57.8 \%)$ responden yang aktif dalam organisasi.

Rendahnya motivasi diri yang terdapat pada 10 orang responden ternyata semua dari program regular. Sesuai dengan penelitian Foster, McCloughen, Delgado, Kefalas, \& Harkness (2015) yang menemukan bahwa kecerdasan emosi seperti kemampuan memotivasi diri dipengaruhi oleh pengalaman klinik sebelumnya.

Rendahnya motivasi diri karena gagalnya pembentukan kemampuan ini saat individu dihadapkan pada situasi yang bisa menumbuhkan keyakinan untuk bangkit dan menemukan alasan yang kuat mencapai sesuatu (Goleman, 2015). Kemampuan memotivasi diri sangat penting bagi mahasiswa perawat, karena dengan kemampuan ini, mahasiswa perawat akan terus mengupgrade diri dan memiliki self development yang baik (Sunaryo, 2008).

\section{Empati}

Hasil penelitian ini menunjukkan bahwa lebih dari setengah responden memiliki empati yang tinggi yaitu 76 orang $(59.4 \%)$ dan ditemukan terdapat 52 orang $(40.6 \%)$ yang memiliki empati yang rendah. Hal ini membuktikan bahwa sebagian besar mahasiswa memiliki empati yang baik namun 
yang memiliki empati yang rendah juga hampir mencapai setengah dari jumlah responden. Sukesi (2012) yang menemukan bahwa tingkat caring perawat di Indonesia masih banyak yang rendah dan ini menunjukkan bahwa adanya masalah pembentukan kecerdasan emosional yang sebagian besar terbentuk pada saat pendidikan (Freshwater \& Stickley, 2009).

Caring merupakan bagian dari empati. Dimana empati merupakan kemampuan merasakan apa yang orang lain rasakan (Goleman, 2015). Kemampuan empati yang rendah membuktikan adanya masalah dalam masa pembentukan kecerdasan emosionalnya (Freshwater \& Stickley, 2009). Dari 52 orang yang memiliki kemampuan empati yang rendah 51 orangnya berasal dari program reguler. Foster, McCloughen, Delgado, Kefalas, \& Harkness (2015) yang menemukan bahwa kecerdasan emosional dimana satu komponennya yaitu empati dipengaruhi oleh pengalaman klinik sebelumnya.

Penelitian ini mengungkapkan bahwa mahasiswa dengan kecerdasan emosi yang rendah juga memiliki skor empati yang rendah. Snowden, Stenhouse, Young, \& Carver, (2015) juga mengatakan bahwa tingkat kecerdasan emosi berbanding lurus dengan skala caring. Empati seperti aktivitas caring memainkan peranan penting dalam kesembuhan pasien. Dengan kemampuan ini, perawat dapat memberikan informasi kepada pasien yang dapat membantunya dalam mengambil keputusan, dan memotivasi pasien untuk sembuh (Linda \& Connoly, 2013). Aktivitas caring terkait dengan kejujuran, pemberian rasa hormat, memberikan informasi ke pasien dan memotivasi pasien untuk sembuh, hal -hal ni merupakan hal yang sangat penting di miliki oleh seorang perawat (Kaur, Sambasivan, \& Kumar, 2015).

Rendahnya kemampuan ini dapat berdampak pada profesi keperawatan kedepannya. Kepedulian pada pasien adalah sangat penting dan merupakan bagian inti dari kinerja perawat.

\section{Social Skill}

Hasil penelitian yang dilakukan tentang gambaran kemampuan mengelola emosi terhadap orang lain (social skill), menunjukkan bahwa sebagian besar responden memiliki social skill yang tinggi yaitu sebanyak 81 orang $(63.3 \%)$ meskipun ditemukan bahwa terdapat 47 orang (36.7 \%) yang memiliki social skill yang rendah.

Hasil penelitian ini juga menemukan bahwa terdapat 47 orang memiliki social skill yang rendah karena mayoritas mereka berada di usia remaja dan berasal dari program regular. Foster, McCloughen, Delgado, Kefalas, \& Harkness (2015) juga menemukan bahwa kecerdasan emosional dan komponennya dipengaruhi oleh pengalaman klinik sebelumnya. Shanta \& Gargiulo (2014) menemukan bahwa kecerdasan emosional mahasiswa senior jauh lebih baik dibandingkan dengan kecerdasan emosional mahasiswa perawat junior. Hal ini membuktikan bahwa adanya proses dalam pembentukan social skill yang terus mengalami perkembangan selama berada pada proses pendidikan. Perawat dengan social skill yang baik akan memiliki sikap, dan sifat yang baik serta akan mampu berkolaborasi dengan profesi kesehatan yang lain serta orang lain (Sunaryo, 2008)

\section{KESIMPULAN}

Penelitian ini mendapatkan bahwa masih banyak mahasiswa yang memiliki social skill yang rendah, dan hal ini akan berdampak pada komponen sikap, dan sifat para mahasiswa keperawatan nantinya. Data yang membuktikan bahwa masih banyak mahasiswa keperawatan yang memiliki social skill yang rendah yang menjawab fenomena terkait mahasiswa keperawatan unhas program reguler yang pada masa profesi sering terkendala masalah sikap. 


\section{DAFTAR PUSTAKA}

Balluerka, N., Gorostiaga, A., Alonso-Arbiol, I., \& Aritzeta, A. (2016). Peer attachment and class emotional intelligence as predictors of adolescents' psychological well-being: A multilevel approach. Journal of Adolescence, 1-9.

Agustian, A. G. (2005). Rahasia sukses membangun kecerdasan emosional dan spiritual. Jakarta: Arga Tilanta.

Arsana, I. J. (2016). Etika profesi . Yogyakarta: Penerbit Deepublish.

Beauvais, A. M., Brady, N., O'Shea, E. R., \& Griffin, M. T. (2011). Emotional intelligence and nursing performance among nursing students. Nurse Education Today, 396-401.

Caruso, D., \& Salovey, P. (2004). The emotionally intelligent manager. San Fransisco: Jossey-Bass.

Dariyo, A. (2015). Ketrampilan Organisasi, Kecerdasan Emosi dan Persahabatan. Psychology Forum UMM, 1-7.

Foster, K., McCloughen, A., Delgado, C., Kefalas, C., \& Harkness, E. (2015). Emotional intelligence education in pre-registration nursing programmes: An integrative review. Nurse Education Today, 510-517.

Freshwater, D., \& Stickley, T. (2009). The heart of the art : emotional intelligence in nursing education. San Fransisco: Jossey-bass.

Goleman, D. (2015). Emotional Intelligence. Jakarta: PT Gramedia Pustaka Utama.

Ilievova, L., Beko, L., \& Dobsovic, L. (2011). Humanistica psycologia $v$ praci sestry. Sestra, 8.

Ilievova, L., Juhasova, I., \& Baumgartner, F. (2013). Opportunities for emotional intelligence in context of nursing. Jornal of health science, 20-25.

Kaur, D., Sambasivan, M., \& Kumar, N. (2015). Impact of emotional intelligence and spiritual intelligence on the caring behavior. Applied Nursing Research, 1-24.

Lekavicienea, R., \& Antiniene, D. (2016). High emotional intelligence: family psychosocial factors. Social and Behavioral Sciences, $609-617$

Linda, S. L., \& Connoly, M. (2013). Using king's interacting systems theory to link emotional intelligence and nursing practice. International Journal of Nursing, 175.

Mayer, J., Salovey, P., Caruso, D., \& Sitarenios, G. (2006). Emotional intelligence as a standard intelligence. Washington DC: Delmar Publishers.

McCobe, C., \& Timmins, F. (2011). Communication skills for nursing practice. New York: Palgrave Macmillan.

McNulty, J., Mackay, S., Lewis, S., Lane, S., \& White, P. (2015). An international study of emotional intelligence in first year. Radiography $\mathrm{xxx}, 1-6$.

Nursalam, \& Efendi, F. (2006). Pendidikan dalam keperawatan. Jakarta: Salemba Medika.

Petrides, K. (2009). Psychometric properties of the trait emotional. The Springer Series, 1-5.

Prasetyo, B. (2009). Metode penelitian kuantitatif. Jakarta: PT RajaGrafindo Persada.

Puspasari, A. (2010). Emotional intelligent parenting. Jakarta: Elex Media Komputindo.

Ranjbar, H. (2015). Emotional intelligence training: A necessity for nursing education curriculum. Nurse Education Today, 1-5.

Shanta, L., \& Gargiulo, L. (2014). A study of the influence of nursing education on development of emotional intelligence. Journal of Professional Nursing, 516-517.

Singh, A., \& Mody, R. (2012). Impact of nuclear and joint family on emotional intelligence among adolescents. 2nd Indian Psychological, 181.

Smith, K. B., Profetto-McGrath, J., \& Cummings, G. G. (2011). Emotional intelligence and nursing: An integrative literature review. International Journal of Nursing Studies, 1624-1636.

Snowden, A., Stenhouse, R., Young, J., \& Carver, H. (2015). The relationship between emotional intelligence, previous caring experience and mindfulness in student nurses and midwives: a crosssectional analysis. Nurse Education Today, 152158.

Stenhouse, R., Snowden, A., Young, J., Carver, F., Carver, H., \& Brown, N. (2016). Do emotional intelligence and previous caring experiencce influence student nurse performance? Nurse Education Today, 7-8.

Sukesi, N. (2012). Upaya peningkatan caring perawat terhadap kepuasan pasien. Jurnal Manajemen Keperawatan, 1-5.

Sunaryo. (2008). Psikologi untuk keperawatan. Jakarta: Penerbit buku kedokteran: EGC. 